\title{
Exploration of cellulolytic potential of Termite gut flora for sustainable development
}

\author{
Bholay A.D, Gaur Apurv,Ganeshan Malarvili, Shah Rameez, \\ Khairnan Bhushan \\ P.G. Microbiology Department, KTHM College, Nashik, Pune University, Maharashtra, India
}

\begin{abstract}
Cellulose is the most abundant organic polymer on Earth. Cellulose is an important structural component of the primary cell wall of green plants. Cellulose degrading bacteria from termite gut flora were isolated, screened and their characterization was studied in relation to cellulase activity. Out of the 16 isolates the three strains, showed higher production of cellulase using CMC and Blotting paper compared to filter paper as sole carbon source. $C D B-W$ utilized $C M C$ in higher level while $C D B-Y$ utilized blotting paper in higher level. The maximum growth was recorded at $\mathrm{pH} 7.0$ and at temperature $30^{\circ} \mathrm{C}$. Among three isolates, the CDB$W$ strain showed higher enzyme activity as compared to other strains. Among carbon sources, maximum growth was observed in fructose amended MSM medium followed by Xylose, Glucose and Starch. Ammonium nitrate and potassium nitrate were good nitrogen sources for growth of $C D B$. The cellulolytic activities of these organisms may be utilized for various industrial and biotechnological applications for sustainable development.

Keywords: Cellulose, Cellulase, CDB, MSM, Termite gut flora.
\end{abstract}

\section{Introduction}

Cellulose is the most abundant biopolymer on Earth. It is a linear polysaccharide (Gupta et al., 2012) assembled from glucose monomer units, and it is the main constituent of plant cell walls. Along with several indigestible polysaccharides, cellulose constitutes the main part of dietary fibre. Specifically cellulose is one of the components of insoluble fibre. Cellulose shows a variable degree of polymerization, with anywhere from 1,000 to 14,000 glucose residues comprising a single cellulose polymer. Because of its high molecular weight and crystalline structure, cellulose is insoluble in water and has a poor ability to absorb water. Cellulose is derived from D-glucose units, which condense through $\beta(1 \rightarrow 4)$-glycosidic bonds. Cellulose is a straight chain polymer.

Cellulase refers to a suite of enzymes produced chiefly by fungi, bacteria, and protozoan's that catalyse cellulolysis (i.e. the hydrolysis of cellulose). Microorganism bring about biodegradation of cellulose in nature using multienzyme complex (Aubert et al,1987). Cellulase enzymes, which can hydrolyze cellulose forming glucose and other commodity chemicals. Cellulase can be divided into three types: endoglucanase (endo-1, 4$\beta$-D-glucanase); cellobiohydrolase or exoglucanase (exo-1, 4- $\beta$-D-glucanase) and $\beta$-glucosidase (1,4- $\beta$-Dglucosidase) (Gupta et al.,2012; Kaur et al.,2012;Abdelnasser et al.,2007;Li et al.2006; Gao et al.,2008). Five general types of cellulases based on the type of reaction catalyzed are Endocellulase, Exocellulase, Cellobiase or beta-glucosidase, Oxidative cellulasesR and Cellulose phosphorylases.Cellulases are important industrial enzymes and find applications in several industrial processes (Hanif et al., 2004; Jamil et al., 2005). Researchers have strong interests in cellulases because of their applications in industries of starch processing, grain alcohol fermentation, malting and brewing, extraction of fruit and vegetable juices, pulp and paper industry and textile industry (Gao et al., 2008).

The purpose of this work was basically to examine the possible utilization of cellulose degrading bacteria from termite (Isopteran) gut, for highest cellulase activity and bacterial growth at optimum working conditions such as $\mathrm{pH}$, temperature and utilization of different carbon and nitrogen sources. This purpose was achieved through different steps; isolation of cellulose bacterial strains from pooled sample; selection of the isolate producing cellulase activity and optimization of physiochemical conditions.

\section{Materials and Methods}

Sample collection and Isolation of cellulose degrading bacteria (CDB) by Enrichment method Cellulose feeding termites were collected from a locality whereby logs of fallen trees were getting decayed. Using 70\% alcohol, termites were surface sterilised. The head and body of each termite was separated (Upadhyaya et al.,2012). Under sterile conditions body of termites were macerated using a sterile rod in $0.9 \%$ sterile saline (Gupta et al.,2012). By using enrichment method cellulose degrading bacteria were isolated. Enrichment culture was made for cellulose degrading bacteria by addition of $1 \mathrm{gm}$ of sample in $250 \mathrm{ml}$ flask containing 100ml Carboxy Methyl Cellulose (CMC) broth (CMC medium employed contained per litre of 
distilled water: $\mathrm{NaNO}_{3}-2$ gm, $\mathrm{K}_{2} \mathrm{HPO}_{4}-1$ gm, $\mathrm{MgSO}_{4}-0.5 \mathrm{gm}, \mathrm{KCl}-2 \mathrm{gm}, \mathrm{CMC}-5$ gm, Peptone - 2 gm, pH 7) and incubated at $30^{\circ} \mathrm{C}$ for $48 \mathrm{hrs}$ under shaking condition at $100 \mathrm{rpm}$ (Balamurgan et al.,2011). After $48 \mathrm{hrs}$ of incubation, enriched broth was spread on the sterile CMC agar plate to obtain the isolated bacterial colonies.

\section{Maintenance of cellulose degrading bacterial culture}

The individual colonies that appeared during isolation studies were subcultured until pure cultures were isolated. Each purified strains were maintained at $4^{0} \mathrm{C}$ on two $\mathrm{CMC}$ agar slants. One slant was stored as stock culture and other was used as working culture.

\section{Screening of isolated cellulose degrading bacteria}

Isolates were screened on the basis of efficiency to degrade cellulose. This was done by the DNSA (3, 5-dinitrosalicylic acid) method. Cellulase activity in cell free culture filtrates were determined by DNSA method through determination of the amount of reducing sugar (Miller, 1959). Using standard graph cellulase activity was determined.

\section{Chemicals and Medium}

Substrate used for the degradation study of cellulose was Carboxy Methyl Cellulose (CMC), filter paper and blotting paper. All other chemicals used were of AR grade and were purchased from Merck (India). Medium used for isolation and degradation studies of cellulose were Carboxy methyl cellulose (CMC) medium. The stock solutions of ingredients were prepared and sterilized separately and then mixed aseptically in appropriate proportions to obtain desired concentrations. The $\mathrm{pH}$ of the medium was adjusted with the help of $\mathrm{NaOH}$ and $\mathrm{HCl}(0.2 \mathrm{~N})$. Medium used for characterization were gelatin agar, starch agar, peptone water, urease agar and other biochemicals.

\section{Characterization and Identification CDB-W isolate}

Colony characteristics and biochemicals were performed with CDB-W isolate. For confirmation, 24 hrs old culture of isolate was characterized using Vitek system and up to $98 \%$ species level identification was obtained.

\section{Determination of the ability to utilize cellulose substrates by CDB strains}

Ability of the isolates to utilize different cellulose sources were checked by inoculating each isolate into MSM broth with different cellulose sources. CMC, filter paper and blotting paper were the different cellulose sources (Balamurgan et al.,2011). 100ml Mineral salt medium broth (MSM broth employed contained per litre of distilled water. $\mathrm{NaNO}_{3}-2 \mathrm{gm}, \mathrm{K}_{2} \mathrm{HPO}_{4}-1 \mathrm{gm}, \mathrm{MgSO}_{4}-0.5 \mathrm{gm}, \mathrm{KCl}-2 \mathrm{gm}$, Peptone - $2 \mathrm{gm}, \mathrm{pH}-7$.) with different $0.1 \%$ cellulose source in it were used and incubated at $30^{\circ} \mathrm{C}$ at $48 \mathrm{hrs}$. Cellulase activity was determined using Updegroff (1969) and Dension and Koehn (1977) method. $3 \mathrm{ml}$ of Acetic acid / Nitric acid and $1 \mathrm{ml}$ of sample was taken in test tube and mixed with help of vortex mixer. Tubes were kept in boiling water bath at $100^{\circ} \mathrm{C}$ for $20 \mathrm{~min}$, and then tubes were cooled and centrifuged at $8000 \mathrm{rpm}$ for $20 \mathrm{~min}$ at RT. Supernatant was discarded and residue washed with D/W. $10 \mathrm{ml}$ of $67 \%$ sulphuric acid was added and allowed to stand for $1 \mathrm{hr}$. After $1 \mathrm{hr}, 1 \mathrm{ml}$ of solution was diluted to $100 \mathrm{ml}$. In diluted solution (1ml), $10 \mathrm{ml}$ of anthrone reagent was added and mixed well. Tubes were kept in boiling water bath for $10 \mathrm{~min}$ and then allowed to cool down. Colour change was measured at $630 \mathrm{~nm}$ (Balamurgan et al., 2011). Procedure was performed in triplicate. The glucose produced by conversion of cellulose may be used for various industrial and biotechnological applications.

\section{Effect of $\mathbf{p H}$ on the growth of cellulose degrading bacteria}

Mineral salt broth with $0.1 \%$ cellulose was prepared and dispensed in test tubes and was adjusted to $\mathrm{pH}$ 4.0, 5.0, 6.0, 7.0 and 8.0. These were inoculated with test cultures and incubated at $37^{\circ} \mathrm{C}$ for $48 \mathrm{hr}$. Following the incubation, growth of the cultures were measured by observation of the optical density at $560 \mathrm{~nm}$ (Balamurgan et al.,2011).

\section{Effect of Temperature on the growth of cellulose degrading bacteria}

MSM broth with $0.1 \%$ cellulose was prepared and dispensed in test tubes; these were inoculated with test cultures and were incubated at different temperatures $\left(25,30,35,40\right.$ and $\left.45^{\circ} \mathrm{C}\right)$. Following the incubation, growth of the cultures was measured by observation of the optical density at $560 \mathrm{~nm}$ (Balamurgan et al.,2011). 


\section{Utilization of different $\mathrm{C}$ and $\mathrm{N}$ sources on the growth of the cellulose degrading bacteria}

To determine the ability of different CDB isolates to utilise different carbon and nitrogen sources, mineral salt broth with $0.1 \%$ of different carbon sources was used. Different carbon sources used were glucose, fructose, maltose, starch, inositol, xylose and citrate (Balamurgan et al., 2011). Similarly, MSM broth with $0.1 \%$ nitrogen source was used for study effect of different nitrogen sources. Nitrogen sources used were ammonium sulphate, sodium nitrate, ammonium nitrate, potassium nitrate, ammonium oxalate, ammonium chloride and urea. After incubation at $30^{\circ} \mathrm{C}$ for $48 \mathrm{hr}$, growth was measured at $560 \mathrm{~nm}$.

Isolation of cellulose degrading bacteria

\section{Results and Discussion-}

Sixteen bacterial isolates were isolated from sample.

\section{Screening of isolated bacteria}

It was found that three bacterial isolates were promising with regard to cellulose degradation efficiency viz-CDB-W, $\mathrm{P}$ and $\mathrm{Y}$. The rate of degradation of cellulose for bacterial isolate $\mathrm{CDB}-\mathrm{W}$ was maximum compared to other two bacterial strains (Fig 1). From the observations it is clearly revealed that the degradation of cellulose is growth associated.

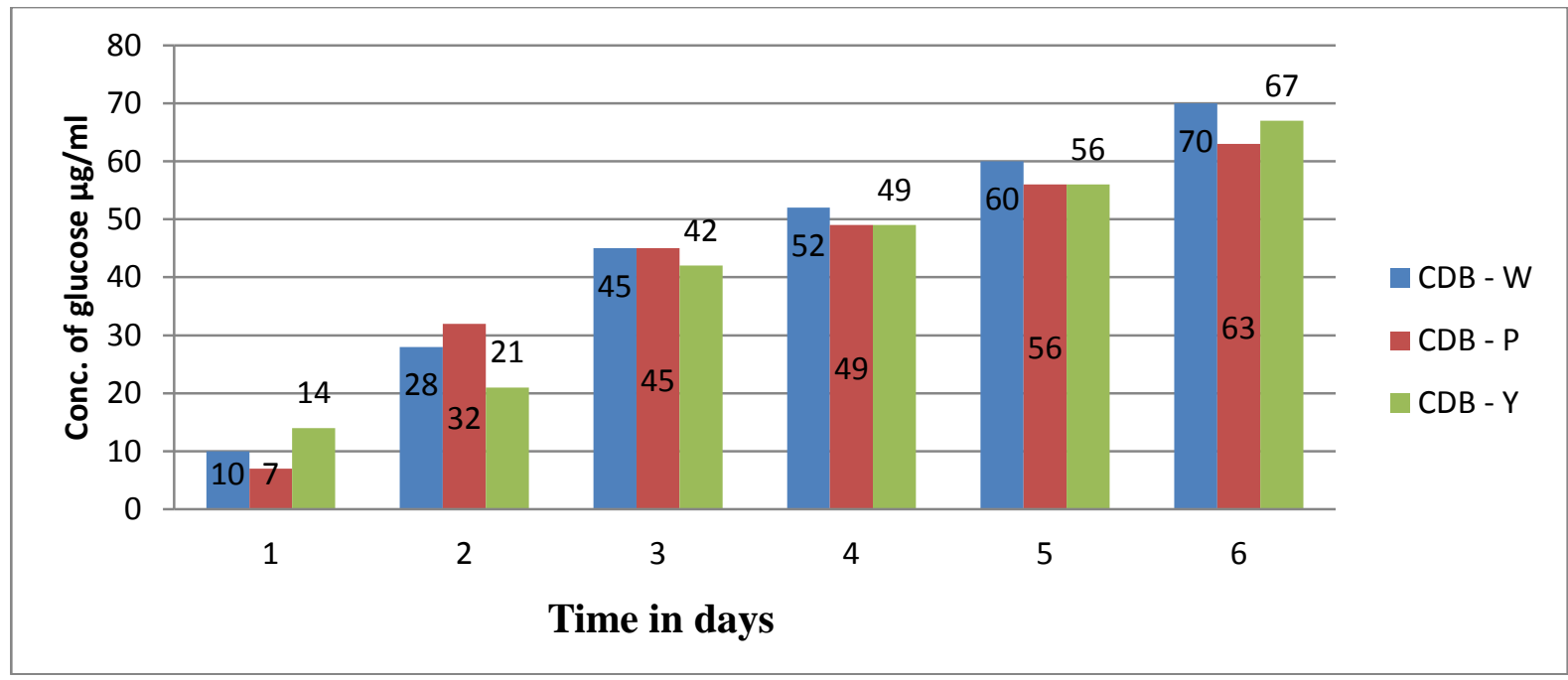

Fig.1. Screening of cellulose degrading bacteria.

\section{Identification of CDB-W isolate}

From the observations of biochemical tests employed as per Bergey's Mannual of Systematic Bacteriology $2^{\text {nd }}$ edition, volume 2, the species of the isolate IV P II rod was identified to be Pseudomonas aeruginosa. This identified organism was further confirmed with VITEK 2 system version 05.02 (Table 1).

Table 1.VITEK-2 system report for identification of the organism.

\begin{tabular}{|c|c|c|c|}
\hline \multicolumn{2}{|c|}{$\begin{array}{l}\text { Bac-test laboratory } \\
\text { Printed Oct 16, } 2013 \text { 19:54 IST } \\
\text { bioMerieux Customer } \\
\text { System \# }\end{array}$} & Laboratory Report & $\begin{array}{l}\text { Printed by bactest } \\
\text { Bench WATER }\end{array}$ \\
\hline $\begin{array}{l}\text { Identification } \\
\text { information }\end{array}$ & Card: GN & $\begin{array}{l}\text { Lot } \\
241215210 \\
\end{array}$ & Expires: Nov 4, 201412.00 IST \\
\hline $\begin{array}{l}\text { Selected } \\
\text { Organism }\end{array}$ & $\begin{array}{c}\text { 98\% Probability } \\
\text { Bionumber: } 0043051\end{array}$ & 03500252 Pseudomonas a & $\begin{array}{l}\text { ruginosa } \\
\text { Confidence: Excellent identification }\end{array}$ \\
\hline
\end{tabular}




\begin{tabular}{|c|c|c|c|c|c|c|c|c|c|c|c|c|c|c|c|c|c|}
\hline \multicolumn{18}{|c|}{ Biochemical details: } \\
\hline 2 & APPA & - & 3 & $\mathrm{ADO}$ & - & 4 & PyrA & - & 5 & IARL & - & 7 & $\mathrm{dCEL}$ & - & 9 & BGAL & - \\
\hline $\begin{array}{l}1 \\
0\end{array}$ & $\mathrm{H} 2 \mathrm{~S}$ & - & $\begin{array}{l}1 \\
1\end{array}$ & BNAG & - & $\begin{array}{l}1 \\
2\end{array}$ & AGLTp & + & $\begin{array}{l}1 \\
3\end{array}$ & dGLU & + & 14 & GGT & + & 15 & OFF & - \\
\hline $\begin{array}{l}1 \\
7 \\
\end{array}$ & BGLU & - & $\begin{array}{l}1 \\
8 \\
\end{array}$ & dMAL & - & $\begin{array}{l}1 \\
9 \\
\end{array}$ & dMAN & - & $\begin{array}{l}2 \\
0 \\
\end{array}$ & dMNE & + & 21 & BXYL & - & 22 & BAlap & + \\
\hline $\begin{array}{l}2 \\
3\end{array}$ & ProA & + & $\begin{array}{l}2 \\
6\end{array}$ & LIP & - & $\begin{array}{l}2 \\
7\end{array}$ & PLE & - & $\begin{array}{l}2 \\
9\end{array}$ & TyrA & - & 31 & URE & + & 32 & $\mathrm{dSOR}$ & - \\
\hline $\begin{array}{l}3 \\
3 \\
\end{array}$ & SAC & - & $\begin{array}{l}3 \\
4 \\
\end{array}$ & dTAG & - & $\begin{array}{l}3 \\
5\end{array}$ & dTRE & - & $\begin{array}{l}3 \\
6\end{array}$ & CIT & + & 37 & MNT & + & 39 & $5 \mathrm{KG}$ & - \\
\hline $\begin{array}{l}4 \\
0\end{array}$ & ILATk & + & $\begin{array}{l}4 \\
1\end{array}$ & AGLU & - & $\begin{array}{l}4 \\
2\end{array}$ & SUCT & + & $\begin{array}{l}4 \\
3\end{array}$ & NAGA & - & 44 & AGAL & - & 45 & PHOS & - \\
\hline $\begin{array}{l}4 \\
6\end{array}$ & GlyA & - & $\begin{array}{l}4 \\
7\end{array}$ & ODC & - & $\begin{array}{l}4 \\
8\end{array}$ & LDC & - & $\begin{array}{l}5 \\
3\end{array}$ & IHISa & - & 56 & CMT & + & 79 & BGUR & - \\
\hline $\begin{array}{l}5 \\
8\end{array}$ & O129R & + & $\begin{array}{l}5 \\
9\end{array}$ & GGAA & - & $\begin{array}{l}6 \\
1\end{array}$ & IMLTa & + & $\begin{array}{l}6 \\
2\end{array}$ & ELLM & - & 64 & ILATa & + & & & \\
\hline
\end{tabular}

\section{Determination of the ability to utilize cellulose substrates by CDB strains}

All three strains, CDB-P, CDB-Y and CDB-W showed higher production of cellulase using CMC and blotting paper compared to filter paper. $\mathrm{CDB}-\mathrm{W}$ utilized $\mathrm{CMC}$ in higher level while $\mathrm{CDB}-\mathrm{Y}$ utilized blotting paper in higher level (Table 2). Cellulase activity of CDB-W strain was greater as comparison to other strains (Table 3). The CDB organisms will select and fix its nutritional and carbon sources based on its availability and physical factors (Abdelnasser et al.,2007; Balamurgan et al.,2011)

Table 2:Cellulose Estimation of CDB Strains using CMC,Blotting Paper and Filter Paper.

\begin{tabular}{|l|l|l|l|l|l|l|}
\hline \multirow{2}{*}{ CDB Strains } & \multicolumn{6}{|c|}{ Cellulose estimation (mg/ml) } \\
\cline { 2 - 7 } & CMC & $\begin{array}{l}\text { Percent } \\
\text { Degradation }\end{array}$ & $\begin{array}{l}\text { Blotting } \\
\text { paper }\end{array}$ & $\begin{array}{l}\text { Percent } \\
\text { Degradation }\end{array}$ & $\begin{array}{l}\text { Filter } \\
\text { paper }\end{array}$ & $\begin{array}{l}\text { Percent } \\
\text { Degradation }\end{array}$ \\
\hline $\begin{array}{l}\text { Initial } \\
\text { Quantity }\end{array}$ & $88.37 \pm 0.73$ & - & $110.18 \pm 0.20$ & - & $130.22 \pm 0.83$ & - \\
\hline CDB $-\mathbf{P}$ & $20.80 \pm 0.17$ & 76.46 & $31.65 \pm 0.12$ & 71.27 & $52.87 \pm 0.76$ & 59.39 \\
\hline CDB - Y & $22.68 \pm 0.54$ & 74.33 & $20.47 \pm 0.13$ & 81.42 & $36.91 \pm 0.45$ & 71.65 \\
\hline CDB - W & $11.31 \pm 0.14$ & 87.20 & $15.83 \pm 0.11$ & 85.63 & $41.19 \pm 0.71$ & 68.36 \\
\hline
\end{tabular}

\section{Effect of $\mathrm{pH}$ on the growth of the cellulose degrading bacteria}

The various range of $\mathrm{pH}$ from 5.0 to 9.0 were tested, the maximum growth of CDB were recorded at $\mathrm{pH} 7.0$ and that even all the strains grew at $\mathrm{pH} 6.0$ to 9.0 (Fig 2). This broad $\mathrm{pH}$ range of the organism for the growth would be helpful in nature for biotransformations.

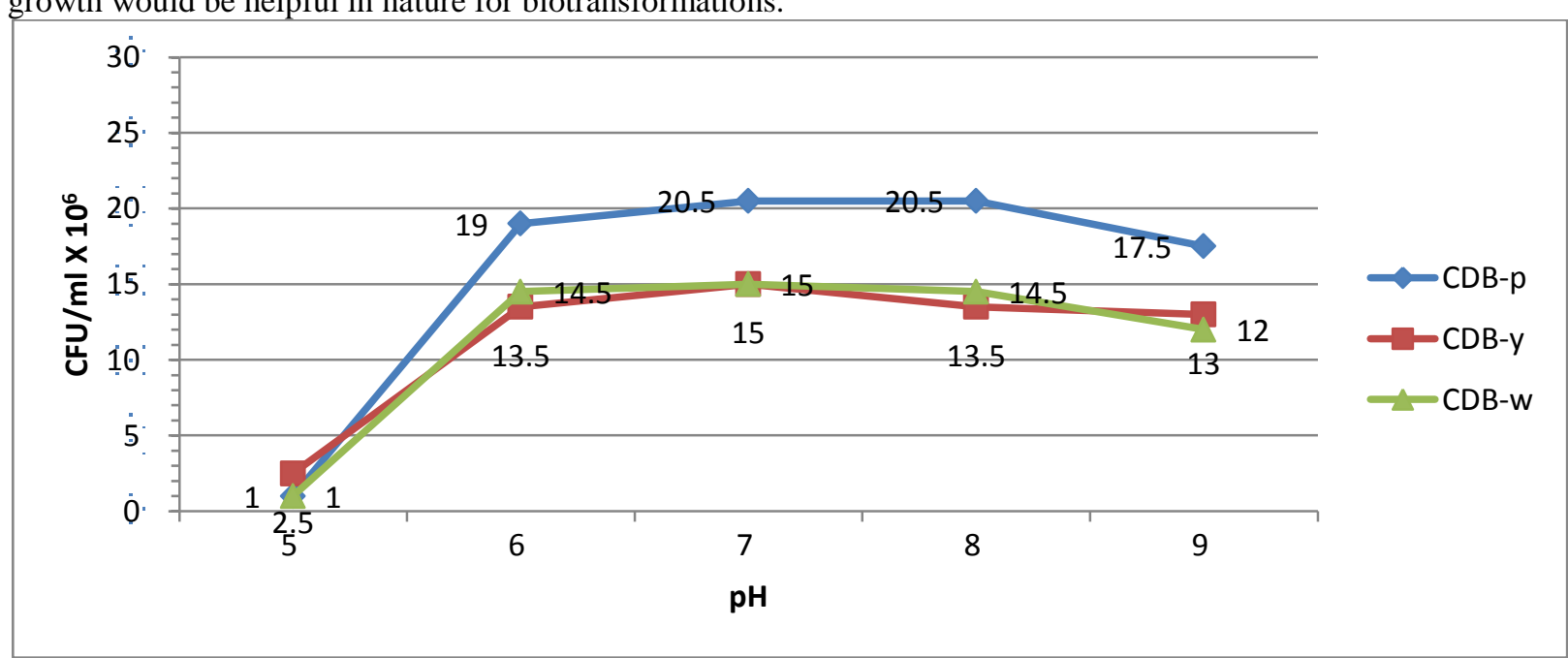

Fig.2. Effect of pH on growth of Cellulose Degrading Bacteria.

Effect of temperature on the growth of the cellulose degrading bacteria

The temperature ranges between $25^{\circ} \mathrm{C}$ to $45^{\circ} \mathrm{C}$ were tested for growth of cellulose degradation bacteria, while the maximum growth of $\mathrm{CDB}$ was observed at $30^{\circ} \mathrm{C}$ (Fig 3$)$. 


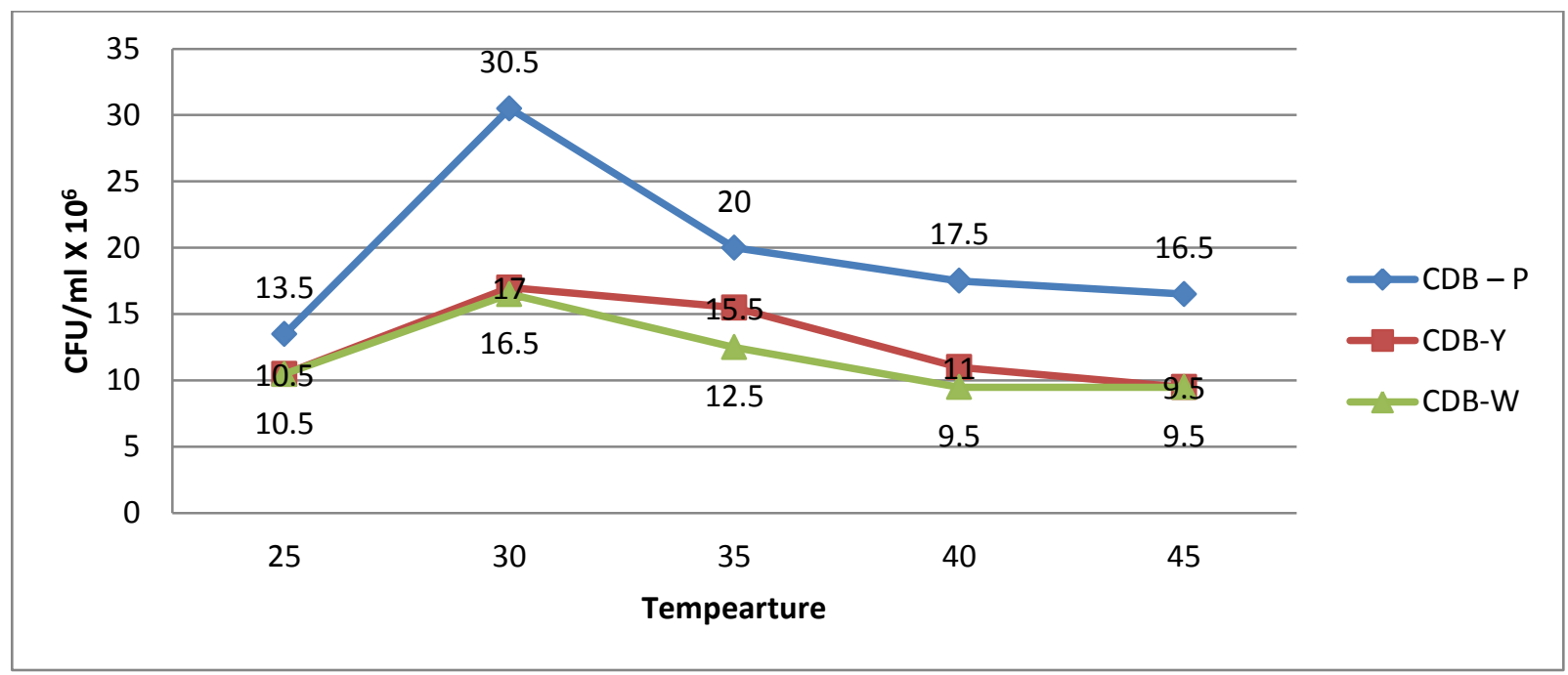

Fig.3. Effect of Temperature on growth of Cellulose Degrading Bacteria.

\section{Effect of different $\mathrm{C}$ and $\mathrm{N}$ sources on the growth of the cellulose degrading bacteria}

All $\mathrm{C}$ and $\mathrm{N}$ sources were able to accelerate the growth of CDB. Among carbon sources, maximum growth was observed in fructose (Balamurgan et al.,2011) amended MSM medium followed by Xylose, glucose and starch. All the nitrogen compounds supported the growth of the cellulose degrading bacteria. Ammonium nitrate and potassium nitrate (Balamurgan et al.,2011) were good nitrogen sources for growth of CDB (Table 3 and 4).

Table 3: Cellulase Activity of CDB Strains using CMC, Blotting Paper and Filter Paper.

\begin{tabular}{|l|l|l|l|l|l|l|}
\hline \multirow{2}{*}{ CDB Strains } & \multicolumn{6}{|c|}{ Cellulase Activity (mg cellulose utilised/hour) } \\
\cline { 2 - 7 } & $\mathbf{C M C}$ & $\begin{array}{l}\text { Cellulase } \\
\text { Activity }\end{array}$ & $\begin{array}{l}\text { Blotting } \\
\text { paper }\end{array}$ & $\begin{array}{l}\text { Cellulase } \\
\text { Activity }\end{array}$ & $\begin{array}{l}\text { Filter } \\
\text { paper }\end{array}$ & $\begin{array}{l}\text { Cellulase } \\
\text { Activity }\end{array}$ \\
\hline Initial Quantity & $88.37 \pm 0.26$ & - & $110.18 \pm 0.85$ & - & $130.22 \pm 1.09$ & - \\
\hline CDB - P & $20.80 \pm 0.13$ & 1.40 & $31.65 \pm 0.11$ & 1.63 & $52.87 \pm 0.30$ & 1.61 \\
\hline CDB - Y & $22.68 \pm 0.22$ & 1.36 & $20.47 \pm 0.77$ & 1.86 & $36.91 \pm 0.98$ & 1.94 \\
\hline CDB - W & $11.31 \pm 0.22$ & 1.60 & $15.83 \pm 0.53$ & 1.96 & $41.19 \pm 1.03$ & 1.85 \\
\hline
\end{tabular}

Table4.Utilization of different nitrogen sources by the CDB strains.

\begin{tabular}{|c|c|c|c|c|c|c|c|}
\hline \multirow{2}{*}{$\begin{array}{l}\text { CDB } \\
\text { Strains }\end{array}$} & \multicolumn{7}{|c|}{ Nitrogen sources (O.D. at $560 \mathrm{~nm}$ ) } \\
\hline & $\begin{array}{l}\text { Ammonium } \\
\text { Sulphate }\end{array}$ & $\begin{array}{l}\text { Sodium } \\
\text { nitrate }\end{array}$ & $\begin{array}{l}\text { Ammonium } \\
\text { nitrate }\end{array}$ & $\begin{array}{l}\text { Potassium } \\
\text { nitrate }\end{array}$ & $\begin{array}{l}\text { Ammonium } \\
\text { oxalate }\end{array}$ & $\begin{array}{l}\text { Ammonium } \\
\text { Chloride }\end{array}$ & Urea \\
\hline CDB-P & 0.05 & 0.11 & 0.95 & 0.81 & 0.22 & 0.11 & 0.14 \\
\hline CDB -Y & 0.09 & 0.09 & 1.48 & 1.20 & 0.18 & 0.09 & 0.10 \\
\hline CDB-W & 0.12 & 0.10 & 1.07 & 1.11 & 0.19 & 0.12 & 0.11 \\
\hline
\end{tabular}

\section{Conclusions}

Cellulose degrading bacteria were successfully isolated from the gut of termites. Among 16 isolates three were more efficient. The three isolates utilized different cellulose sources with preference to blotting paper and CMC. CDB-W isolates had shown maximum cellulase activity at $\mathrm{pH} 7.0$ and at temperature $30^{\circ} \mathrm{C}$. The effect of $\mathrm{pH}$ and temperature was similar to previous studies on activity of cellulose (Balamurgan et al.,2011; Chung et al, 2009). Glucose, fructose, xylose and starch had shown to accelerate degradation activity while among nitrogen sources, ammonium nitrate and potassium nitrate were found to accelerate degradation activity. Among three isolates, $\mathrm{CDB}-\mathrm{W}$ was found to be most efficient for biodegradation of cellulose and was identified as Pseudomonas aeruginosa. Cellulolytic potential of termite gut flora for sustainable development was efficiently explored and could be effectively used in nature for sustainable biotransformations. 


\section{References}

[1]. Gupta Pratima, Samant Kalpana, and Sahu Avinash, Isolation of Cellulose-Degrading Bacteria and Determination of Their Cellulolytic Potential.International Journal of Microbiology,2011pg 1-5.

[2]. Aubert JP, Beguin P, Millet J, Biochemistry and Genetics of cellulose degradation, fungal and bacterial enzyme systems and their manipulation. FEMS symposium. 43,Academic press, new York, 1987 11-30.

[3]. Kaur Manmeet and Dr.Arora S,. Isolation and Screening of Cellulose Degrading Bacteria in Kitchen Waste and Detecting Their Degrading Potential. IOSR Journal of Mechanical and Civil Engineering (IOSRJMCE)2012, 33-35.

[4]. Abdelnasser SSI, Ahmed IE, Isolation and identification of new cellulose producing thermophilic bacteria from an Egyptian hot spring and some properties of the crude enzyme. Austr. J. Basic App. Sci, 1(4);2007 473-478.

[5]. Li, Y.H., M. Ding, J. Wang, G.J. Xu and F. Zhao, A novel thermo acidophilic endoglucanase, Ba-EGA, from a new cellulose degrading bacterium, Bacillus sp. AC-1. Appl. Microbiol. Biotechnol, 70:2006 430-436.

[6]. Gao, J., H. Weng, D. Zhu, M. Yuan, F. Guan and Yu Xi, Production and characterization of cellulolytic enzymes from the thermo acidophilic fungal Aspergillusterreus M11 under solid state cultivation of corn stover. Bioresour. Technol., 99:2008 7623-7629.

[7]. Hanif, A., A. Yasmin and M.I. Rajoka., Induction, production, repression and de-repression of exoglucanase synthesis in Aspergillusniger. Bioresour. Technol., 94:2004 311-319.

[8]. Jamil, A., S. Naim, S. Ahmed and M. Ashraf., Production of Industrially important enzymes using molecular approaches; cellulases and xylanases. In: Genetic resources and Biotechnology II, Volume Two, (Eds.): D. Thangadurai, T. Pullaiah, Pedro and A. Balatti. Regency publications, 7; 2005 143-183 New Delhi.

[9]. Upadhyaya S K, Manandhar A, Mainali A, Pokhrel A R, Rijal A, Pradhan B, Koirala B, Isolation and Characterization of Cellulolytic Bacteria from Gut of Termite, Rentech Symposium Compendium, 2012 pg 14-18

[10]. Balamurgan A., Jayanthi R., Nepolean P., VidhyaPallavi R and Premkumar R, Studies on cellulose degrading bacteria in tea garden soil, African journal of plant science, 2011 pg22-27.

[11]. Miller GL, Use of dinitrosalicylic acid reagent for determination of reducing sugar. Anal chem.,31:1959 426-428.

[12]. Updegroff DM,. Semi micro determination of cellulase in Biological Materials. Anal Biochem, 32; 1969 420-424.

[13]. Dension DA, Koehn RD, Cellulose activity of Poroniaoedipus. Mycologia, 69;1977592-603.

[14]. Chung-Yi W, Yi-Ru H, Chang-Chai , Helen C, Hsin-Tang L, Wen- Sheng T, Yuan-Tay S, Purification and characterization of new halostable cellulase from salinivibrio sp. Strain NTU-05. Enzyme and microbial technology-Elsevier, 44;2009373-379. 